Geochemical Journal, Vol. 1, pp. 109 to 124, 1967.

\title{
Decomposition process of organic carbon and nitrogen in lake water
}

\author{
Tadashiro Koyama and Takao Tomino \\ Water Research Laboratory, Faculty of Science, \\ Nagoya University, Chikusa, Nagoya, Japan
}

(Received April 24, 1967)

\begin{abstract}
Weight ratios of organic carbon to nitrogen in plankton, detritus settled at $25.5 \mathrm{~m}$ through $28.5 \mathrm{~m}$ water depths, and bottom surface sediments in Lake Kizaki-ko (max. depth: $28.5 \mathrm{~m}$ ) are 5.7, 10.7 and 15.5 respectively. This suggests that in the lake water the nitrogenous fraction of dead planktonic material is more easily mineralized microbiologically than the carbonaceous fraction. The seasonal observation of the chemical components in the lake water shows the following facts: (1) During the early stage of a stagnation period, nitrogen fixation is generally more active than denitrification. On the contrary, denitrification gradually exceeds nitrogen fixation with the progress of stagnation. (2) At the end of the stagnation period, the amount of denitrified $\mathrm{N}_{2}$ is considerably large as compared with those of the other mineralized nitrogenous compounds, and the denitrification constitutes the dominant process determining nitrogen metabolism in the lake water. (3) The average ratio of total mineralized carbon to nitrogen at the end of the stagnation period is 3.5 , a value considerably smaller than the corresponding value for plankton, 5.7. This fact supports the view that the greater ease for the mineralization of nitrogenous fraction in dead planktonic material as compared with that of carbonaceous fraction causes the increase in the ratio of org. C/org. N of organic detritus from upper water layers towards the bottom. (4) The mineralization rates of carbon and nitrogen in the organic detritus in the lake water are $51 \% / y$ and $76 \% / y$ respectively.
\end{abstract}

\section{INTRODUCTION}

The organic matter found within a lake or in its sediments is obviously either autochthonous or allochthonous. The organic matter of the former type is what has been formed within the basin, originally by the photosynthetic activity of green plants living in the lake, and the latter is what has been formed outside the basin and carried into it by water or wind. With the exception of particularly small or shallow lakes, main source of organic matter found in a lake may be plankton which contains more proteins and fats than does terrestrial vegetation. Soon after the death of plankton, the planktonic detritus begins to precipitate and is subjected to microbiological decomposition first in oxic zone and later in anoxic zone, and finally settles on the bottom surface forming a fresh organic sediment.

The mineralization of organic matter usually is highly advanced under aerobic condition. However, it is practically halted under anaerobic condition which prevails in bottom sediments as shown in the results from laboratory experiments conducted 
by Botan et al. (1960) and WAKSMAN (1933). Experiments dealing with the decomposition of plankton and the regeneration of nutrients in vitro and under laboratory conditions have been performed by many researchers. BotAN et al. (1960) reported a mechanism for the aerobic decomposition of nitrogenous matter in fresh water under laboratory conditions. KLEEREKOPER (1953) discussed the mineralization of plankton in lake water, and SAIJo (1956) reported chemical studies on the production and mineralization of plankton in lake water. TANAKA (1954) found out the occurrence of hydroxylamine as one of the intermediate breakdown products from nitrogenous organic matter at the boundary between anoxic and oxic water layers in a lake. Von Brand et al. $(1937,1939,1940,1941,1942)$ discussed the process of decomposition and regeneration of nitrogenous organic matter in sea water. Duursma (1961) reported dissolved organic carbon, nitrogen, and phosphorus in sea water, and FrAGA (1966) discussed the distribution of particulate- and dissolved-organic nitrogen in the western Indian Ocean and found that the ratio of particulate organic carbon to particulate organic nitrogen increases with depth. OANA (1957) first found out denitrified $\mathrm{N}_{2}$ in aerobic water as well as in anaerobic water, the amount of which ranged between 0.06 and $0.38 \mathrm{ml} / 1$ in Lake Kizaki-ko and between 1.01 and $1.65 \mathrm{ml} / 1$ in Lake Nakatsuna-ko respectively in August, 1949.

Koyama and Tomino (1967) have found that the ratio of organic carbon to nitrogen in detritus increases with depth in Lake Kizaki-ko and discussed briefly the mechanism which causes the increase in the ratio. The present study is intended to estimate more correctly the ratio of total mineralized carbon to total mineralized nitrogen, which should be a clue to elucidate the mechanism of mineralization of organic matter, and also to estimate the mineralization rates of carbon and nitrogen in organic detritus in lake water on the basis of fairly abundant data obtained from the seasonal observations from May 1963 through October 1966.

\section{EXPERIMENTAL}

\section{Chemical analysis}

Dissolved oxygen and the other gases combined except total carbon dioxide were analysed in situ by using the carbon dioxide method (SugAWARA, 1939) modified by OANA (1957) and Koyama as shown in Fig. 1; nitrogen, argon and methane by using gas-chromatography; total carbon dioxide by using the hydrogen method (Koyama, 1954); hydroxylamine by using the method of ENDRES

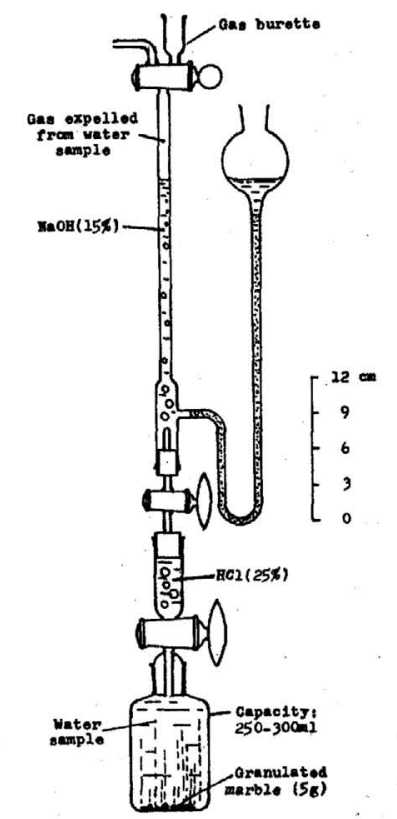

Fig. 1. Apparatus for determining oxygen and total other gases dissolved in water. 
and KaUfmanN (1937); nitrite by using Griess' reagent; nitrate by using copper sulfate, hydrazine sulfate, and .Griess' reagent (MULLIN and RILEY, 1955); total manganese by using silver oxide as oxidizing reagent (TANAKA, $1951 \mathrm{a}, \mathrm{b}$ ); ferrous by using 2,2'-bipyridyl and acetate buffer; organic carbon (org. C) by using the wet combustion method modified by Koyama (1954); organic nitrogen (org. N) by using the Kjeldahl method modified by Koyama (1954).

Calculation of denitrified (or fixed) nitrogen

The amount of denitrified (or fixed) $\mathrm{N}_{2}$ was calculated according to the following equation:

$$
\Delta \mathrm{N}_{2}(\mathrm{ml} / 1)-\mathrm{N}_{2(\text { obs.) }}(\mathrm{ml} / \mathrm{l})-\mathrm{N}_{2(\text { theor.) }}(\mathrm{ml} / \mathrm{l}),
$$

where $\Delta \mathrm{N}_{2}$ indicates the amount of denitrified (for positive values) or fixed (for negative values) nitrogen. $\mathrm{N}_{2 \text { (obs.) }}$ indicates the amount of nitrogen dissolved in water sample and was determined as follows:

(1) The total gases except $\mathrm{O}_{2}$ and total $\mathrm{CO}_{2}$ were determined on board, transferred into a gas tube and brought to laboratory to be analysed for its gaseous composition.

(2) $\mathrm{N}_{2}, \mathrm{Ar}$, and $\mathrm{CH}_{4}$ in the gas tube were determined by using a gas chromatograph which had been carefully standardized with gas mixtures.

(3) From the determined composition and the observed amounts of total gases, each amount of $\mathrm{N}_{2}, \mathrm{CH}_{4}$ and $\mathrm{Ar}$ was determined within an error of $\pm 0.2 \%$ for $\mathrm{N}_{2}$ and $\mathrm{CH}_{4}$ and $\pm 1 \%$ for $\mathrm{Ar}$.

$\mathrm{N}_{2 \text { (theor, }}$ indicates the theoretically calculated amount of nitrogen in water when it was saturated with air at the surface of a lake. It is calculated from the determined amount of argon and the amounts of argon and nitrogen in water saturated with air, which were presented by OANA (1957). The amount of denitrified (or fixed) $\mathrm{N}_{2}$ calculated accompanies an unavoidable error of $\pm 0.1 \mathrm{ml} / 1$.

\section{Results and Discussion}

Ratio of organic carbon to nitrogen in settling detritus

The weight ratios of organic carbon to nitrogen of plankton, detritus settled at four different depths from $25.5 \mathrm{~m}$ through $28.5 \mathrm{~m}$, and bottom surface sediments in Lake Kizaki-ko (maximum depth: $28.5 \mathrm{~m}$; area: $1.413 \mathrm{~km}^{2}$ ), which is a mesotrophic lake in Nagano Prefecture, Japan, were 5.7, 10.7, and 15.5 respectively as shown in Table 1. Such an increase in the ratio with depth was also found in the vertical distribution of the ratio of particulate organic carbon to particulate organic nitrogen found by FrAGA (1966) in the western Indian Ocean. This suggests that in lake and ocean the nitrogenous fraction of dead planktonic material is more easily mineralized microbiologically than the carbonaceous fraction. In order to solve the problem seasonal observation was carried out for chemical components in Lake Kizaki-ko from May, 1963 through October, 1966. 
Table 1. Average ratios of organic carbon to nitrogen of plankton, detritus settled at $25.5 \mathrm{~m}$ through $28.5 \mathrm{~m}$ levels, and bottom surface sediments in Lake Kizaki-ko

\begin{tabular}{lc}
\hline & Org. C/Org. N \\
\hline Plankton & 5.7 \\
Detritus settled at $25.5 \mathrm{~m}$ through $28.5 \mathrm{~m}$ levels & 10.7 \\
Bottom surface sediments & 15.5 \\
\hline
\end{tabular}

(Maximum depth of the lake: $28.5 \mathrm{~m}$ )

Vertical distribution of various chemical components in lake water and its seasonal variation

The vertical distributions of various chemical components in Lake Kizaki-ko are given in Figs. 2, 3, 4, 5, 6, 7, 8, 9, 10, 11, and 12 in the order of stagnation degree with respect to the vertical distributions of temperature and dissolved oxygen.

Fig. 2 shows a chemical feature during a circulation period in winter. The vertical distributions of water temperature, total carbon dioxide, dissolved oxygen, $\mathrm{NH}_{4}^{+}-\mathrm{N}$ and $\mathrm{NO}_{3}^{-}-\mathrm{N}$ are uniform because of the active mixing of the lake water. Fixed nitrogen and denitrified nitrogen are found at various depths. However, they are considerably small.

Fig. 3 shows a chemical feature at an intermediate stage between the end of winter circulation period and the beginning of spring stagnation period. A weak thermal stratification has been established and thus the total $\mathrm{CO}_{2}$ slightly increases with depth in contrast with the dissolved oxygen and also a weak nitrogen fixation

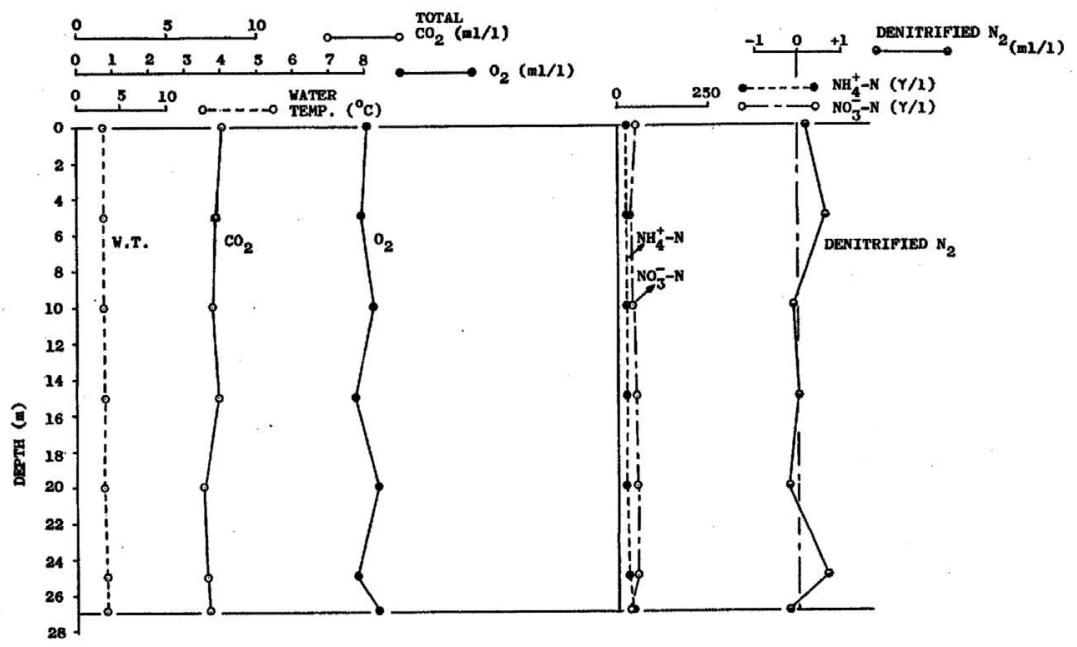

Fig. 2. Vertical distribution of various components in Lake Kizaki-ko. I. (March 14, 1965) 


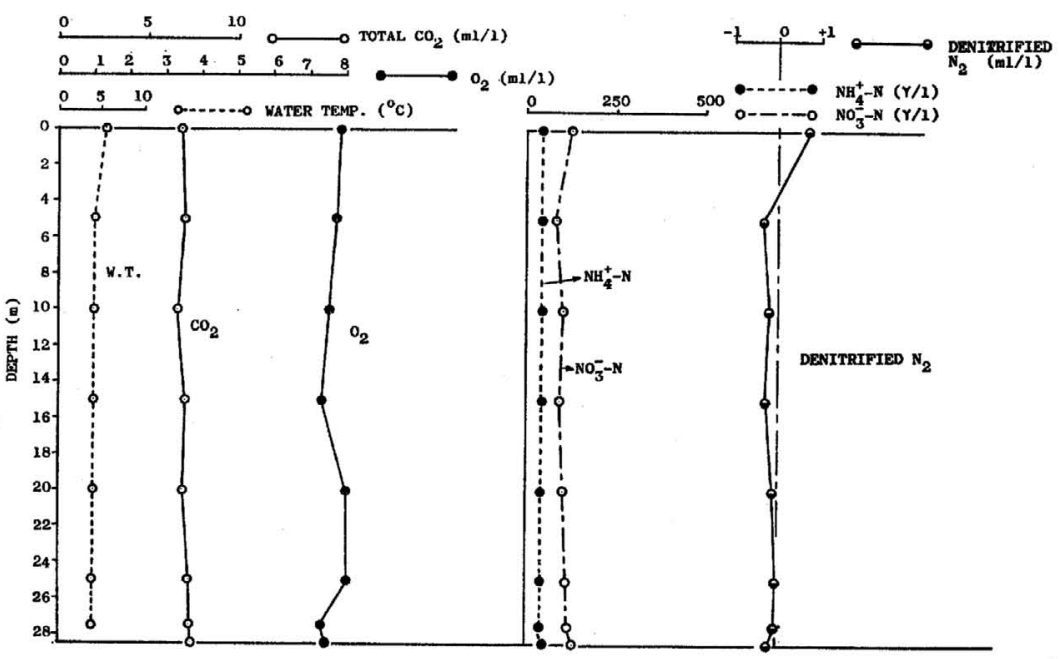

Fig. 3. Vertical distribution of various components in Lake Kizaki-ko. II. (March 12-13, 1966)

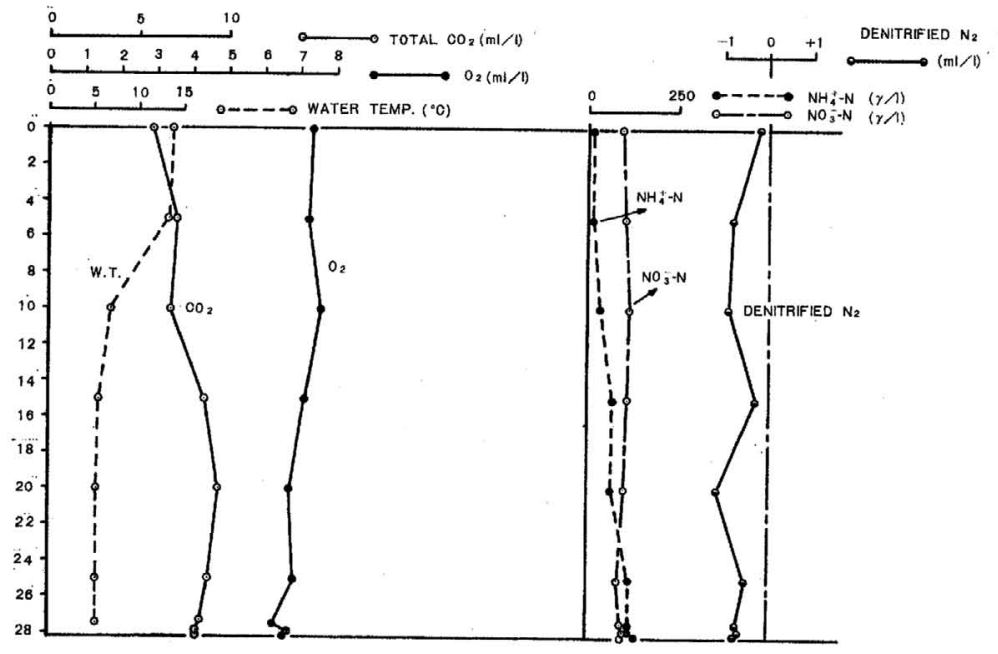

Fig. 4. Vertical distribution of various components in Lake Kizaki-ko. III. (April 25, 1964)

takes place in all water layers with an exception of the surface water layer.

Fig. 4 shows a typical distribution at the beginning of spring stagnation period. Dissolved oxygen slightly decreases downwards, while total carbon dioxide slightly increases downwards. Ammonium nitrogen slightly increases with depth, and nitrate nitrogen, however, is uniformly distributed in all depths. Nitrite and hydroxylamine do not yet appear in any water layer which știll reșęrves oxygen. Most 


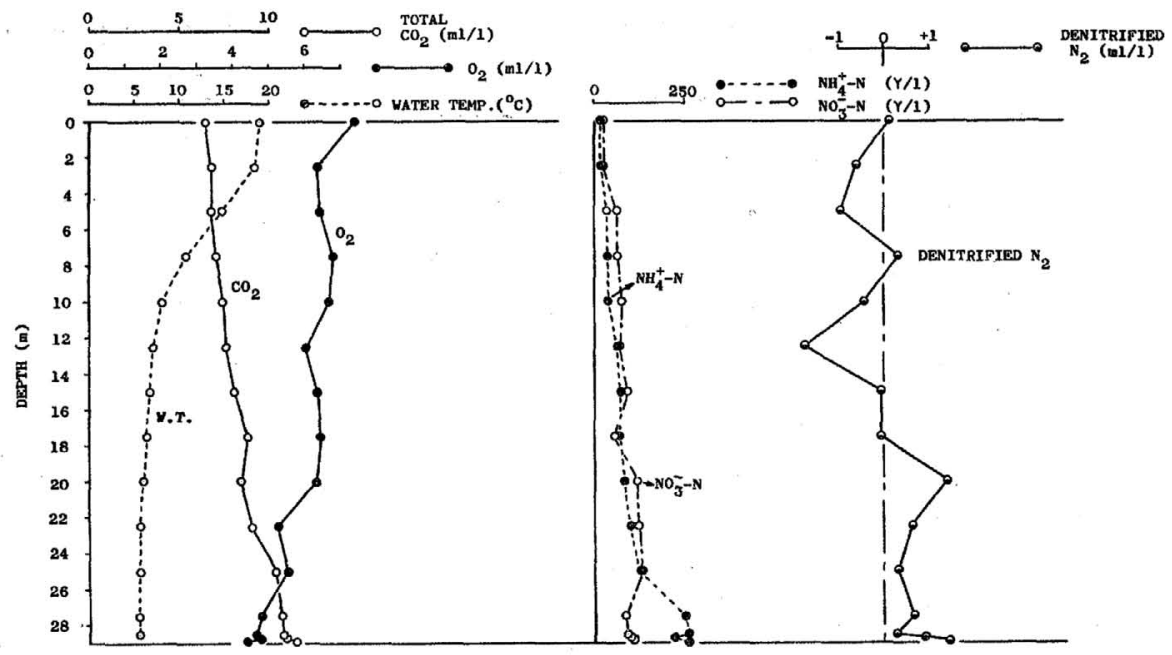

Fig. 5. Vertical distribution of various components in Lake Kizaki-ko. IV. (May 31, 1963)

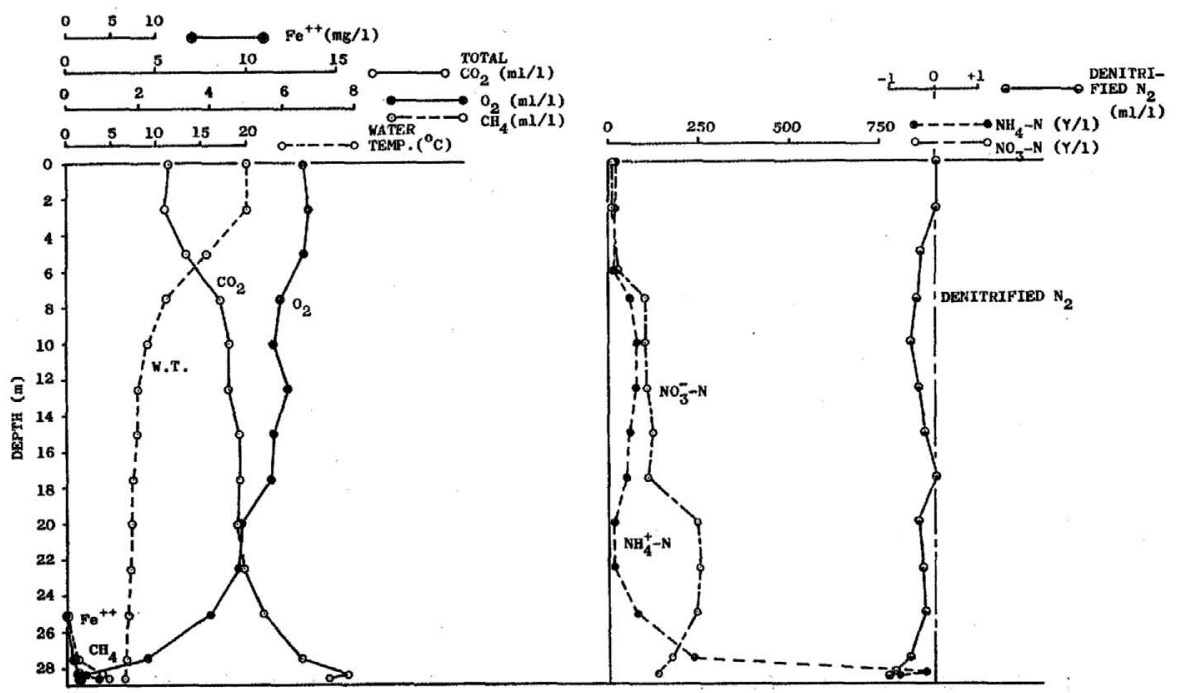

Fig. 6. Vertical distribution of various components in Lake Kizaki-ko. V. (July 11-12, 1965)

remarkable is that nitrogen fixation actively takes place in all water layers reflecting the spring bloom.

Fig. 7 shows a chemical feature at the middle of a stagnation period. Dissolved oxygen rapidly decreases with depth and is completely absent in the water layer deeper than $28.0 \mathrm{~m}$, where small amounts of $\mathrm{Fe}^{2+}$ and $\mathrm{CH}_{4}$ appear. In contrast 


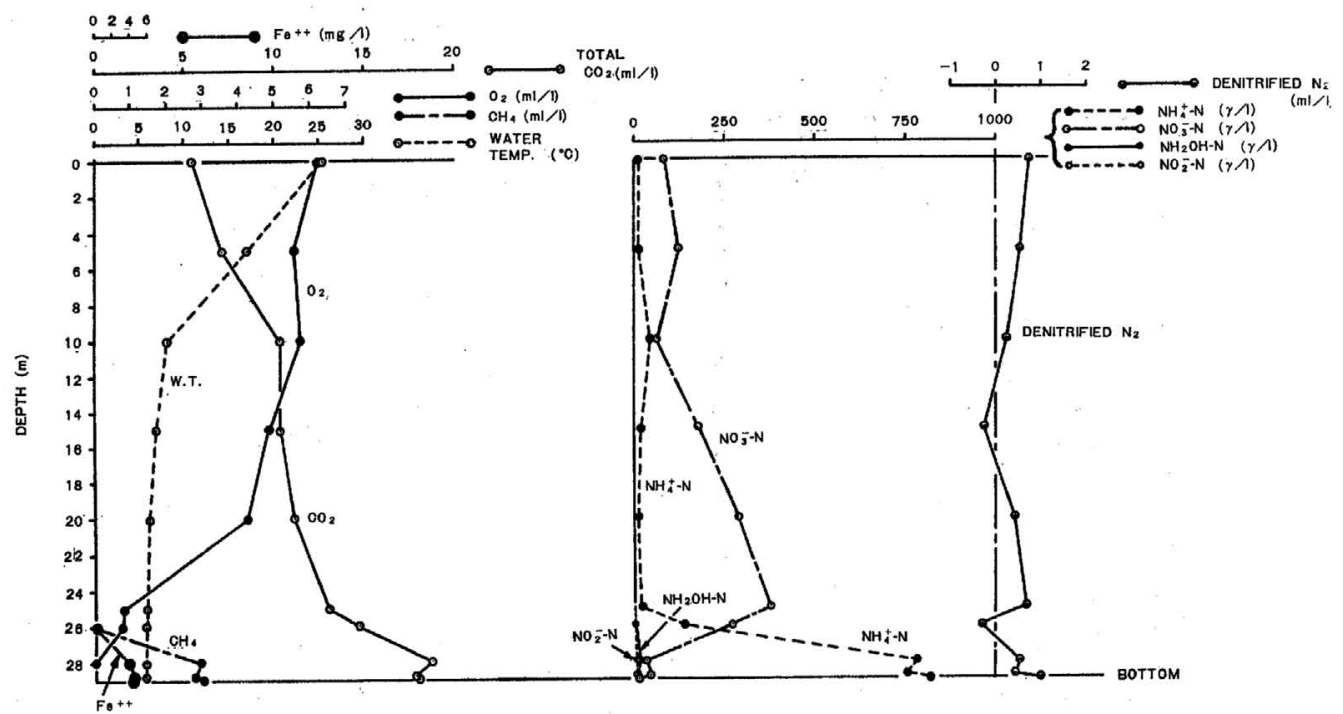

Fig. 7. Vertical distribution of various components in Lake Kizaki-ko. VI.

( July 28, 1964)

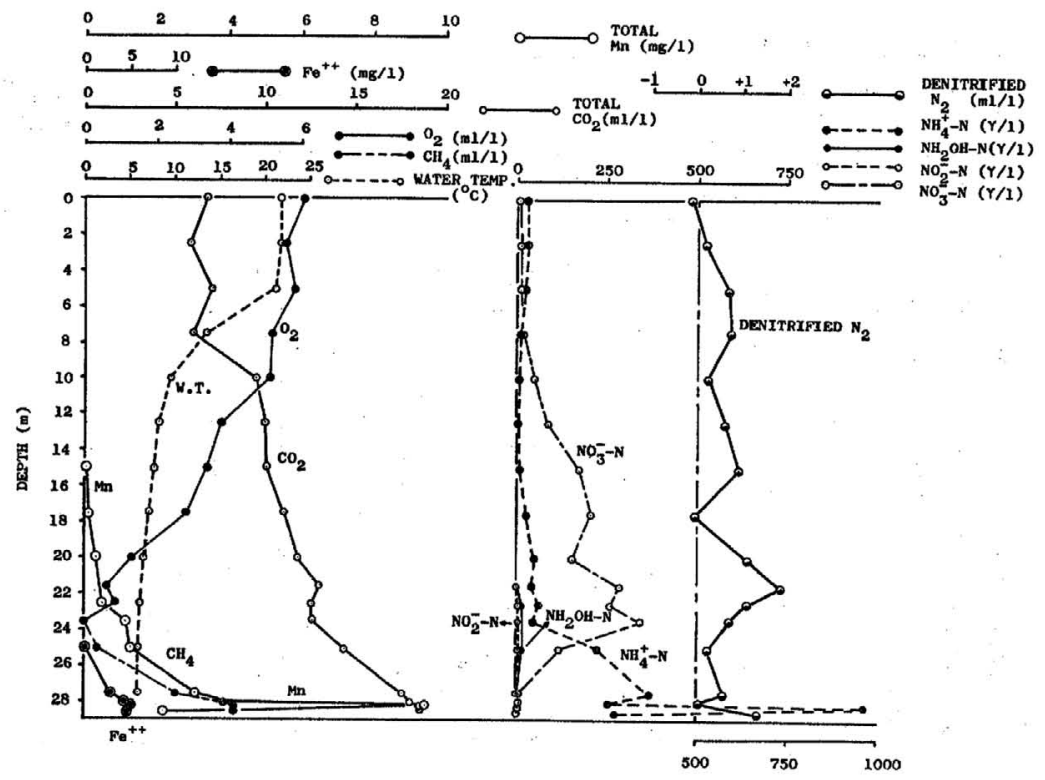

Fig. 8. Vertical distribution of various components in Lake Kizaki-ko. VII. (September 7-8, 1963) 


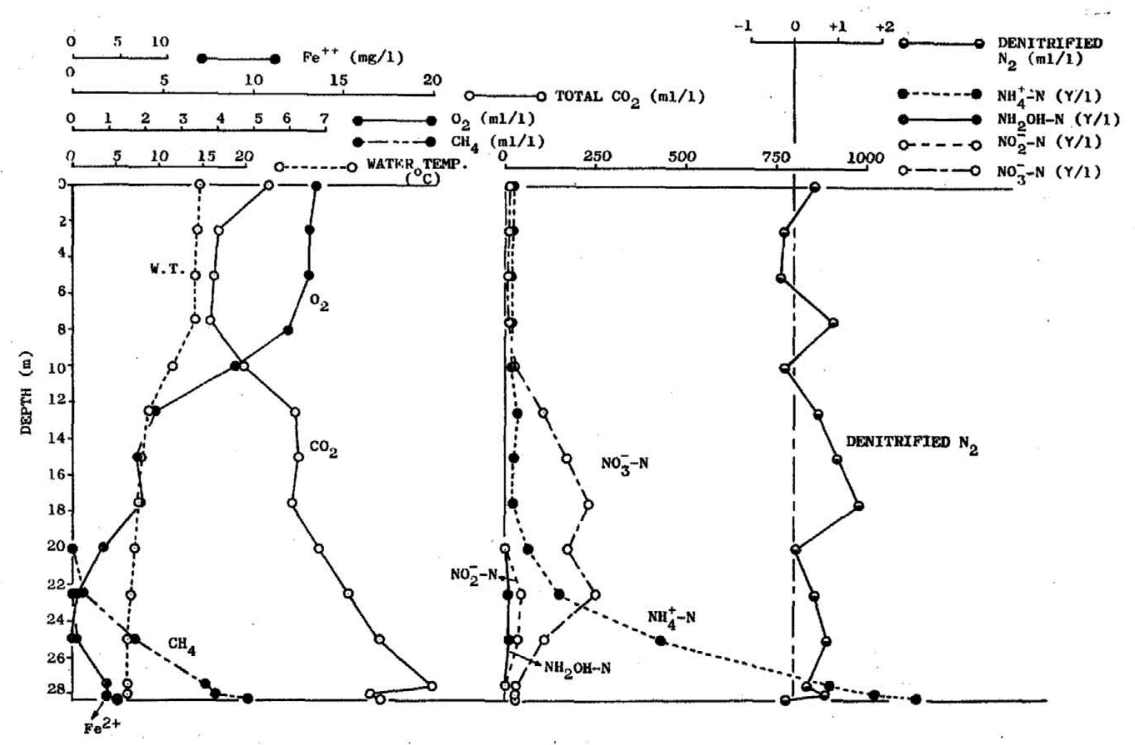

Fig. 9. Vertical distribution of various components in Lake Kizaki-ko. VIII. (October 31, 1966)

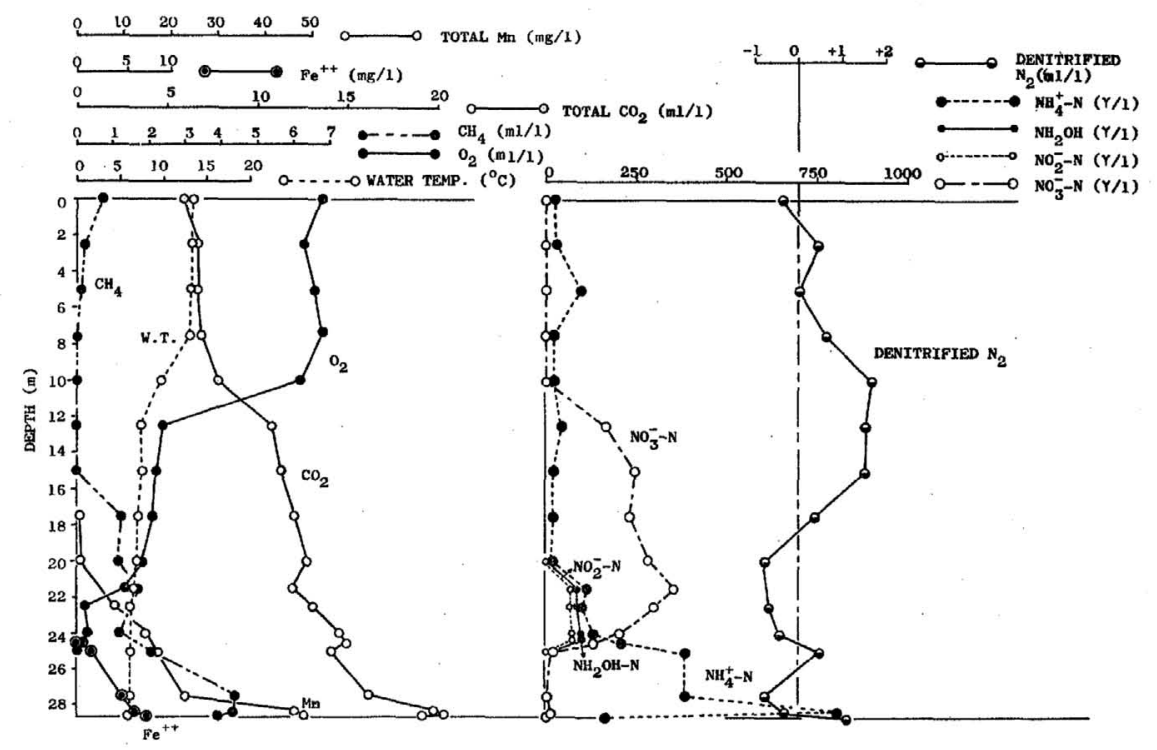

Fig. 10. Vertical distribution of various components in Lake Kizaki-ko. IX. (Oçtober 28-31, 1963) 


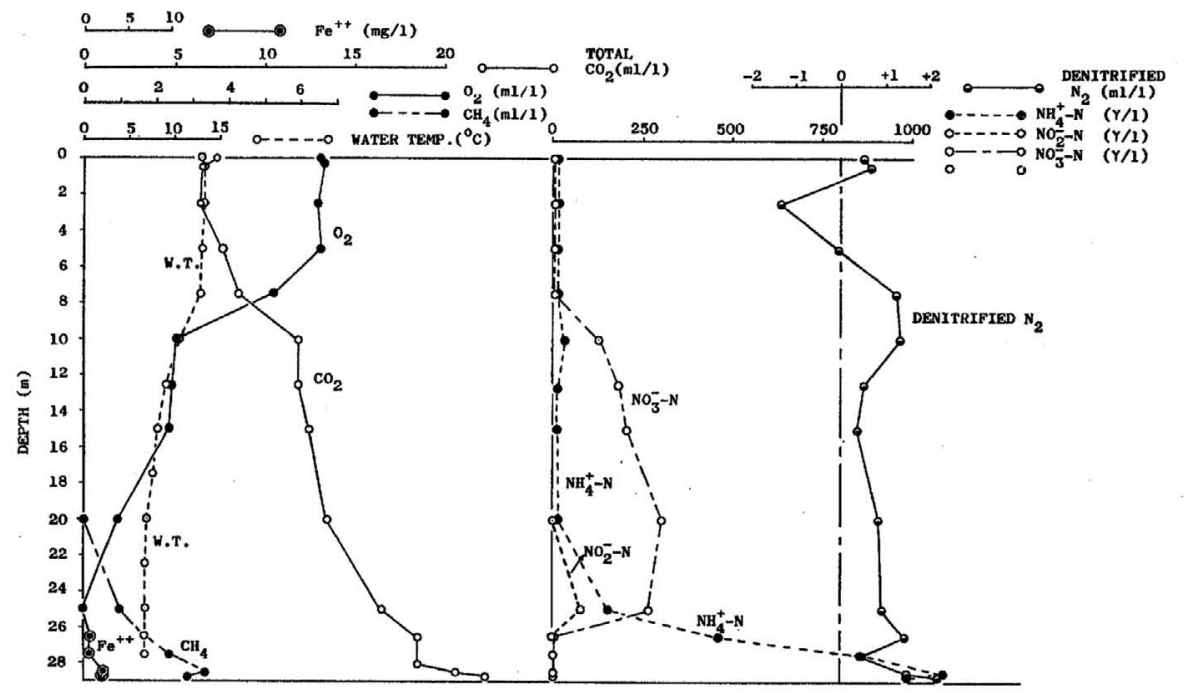

Fig. 11. Vertical distribution of various components in Lake Kizaki-ko. X. (November 1-2, 1965)

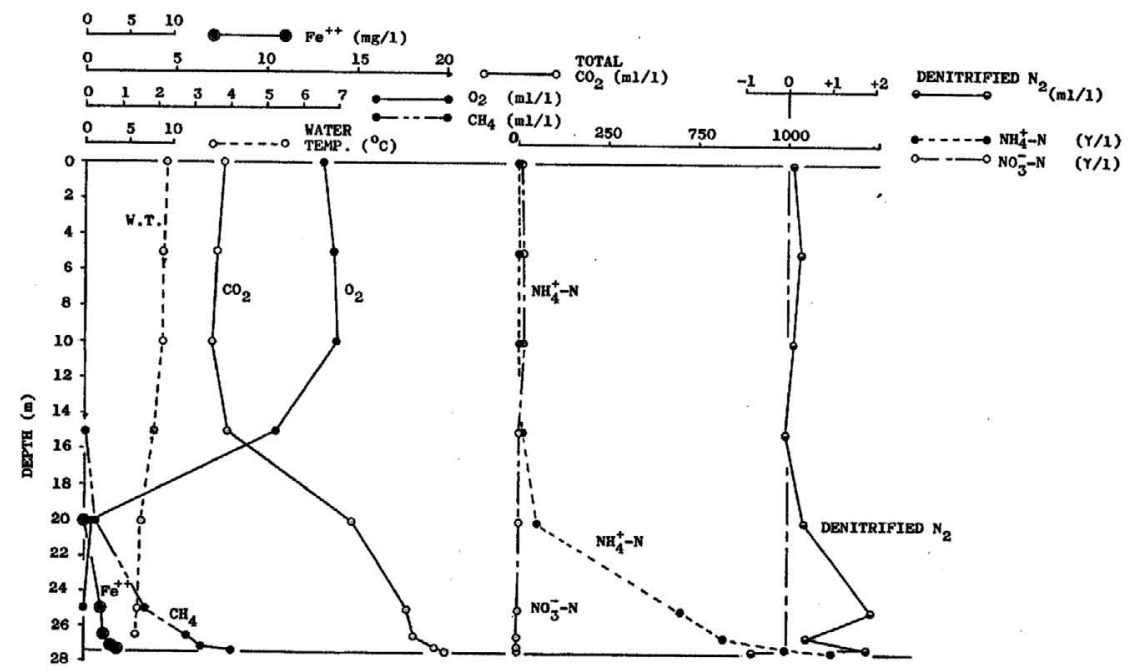

Fig. 12. Vertical distribution of various components in Lake Kizaki-ko. XI, (November 21, 1964) 
with dissolved oxygen total carbon dioxide remarkably increases downwards. The amount of $\mathrm{NH}_{4}^{+} \cdot \mathrm{N}$ is small and is uniformly distributed in the water layers from surface to $25 \mathrm{~m}$ depth. In the deeper water layers, however, it strikingly increases towards the bottom surface, being supplied from the bottom sediments. The amount of $\mathrm{NO}_{3}^{-}-\mathrm{N}$ increases with depth down to $25 \mathrm{~m}$ and from there downwards remarkably decreases to be almost absent at the bottom surface. Small amounts of $\mathrm{NO}_{2}^{-}-\mathrm{N}$ and $\mathrm{NH}_{2} \mathrm{OH} \cdot \mathrm{N}$ appear at $28 \mathrm{~m}$ depth which is the boundary between oxic and anoxic zones. Denitrification slightly takes place in all water layers from surface to bottom except for water layers at $15 \mathrm{~m}$ and $26 \mathrm{~m}$ depths, where weak fixation of nitrogen is observed.

Fig. 8 and Table 2 show a typical distribution at the end of summer stagnation period, which is very similar to that in October, 1966, (Fig. 9). Dissolved oxygen rapidly decreases downwards and completely disappears in the water layer deeper than $23.5 \mathrm{~m}$. In contrast with dissolved oxygen, total carbon dioxide remarkably increases with depth. Total $\mathrm{Mn}$ begins to appear in the water layer at $15 \mathrm{~m}$ and remarkably increases downwards from $23.5 \mathrm{~m}$ probably as a result of accumulation of $\mathrm{Mn}^{2+}$. $\mathrm{Fe}^{2+}$, however, does not yet appear at $23.5 \mathrm{~m}$, where dissolved oxygen has already disappeared, and then increases with depth. Ammonium nitrogen increases with depth and amounts to $960 \mathrm{r} / 1$ in the water layer lying just above the bottom surface. Ammonium nitrogen has been derived probably from particulate organic matter raining down into the stagnant bottom water and also from bottom sediments. Particulate organic matter is probably the main source of ammonium ions in the lake water. Nitrate nitrogen increases with depth to the uppermost layer

Table 2. Vertical distribution of various components in Lake Kizaki-ko

(September 7-8, 1963)

\begin{tabular}{|c|c|c|c|c|c|c|c|c|c|c|c|c|c|c|}
\hline 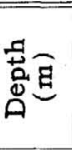 & 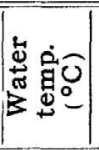 & 罟 & ธี & 记畐 & 点要 & $\left|\begin{array}{cc}0 & 0 \\
0 & 0\end{array}\right|$ & 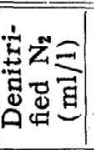 & 学 & $\begin{array}{l}Z \\
0^{\prime}= \\
0^{\prime}\end{array}$ & $\begin{array}{l}z \\
10 \\
0 \\
0 \\
z=\end{array}$ & 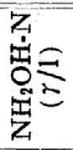 & 实言 & 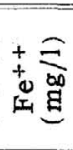 & 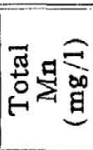 \\
\hline 0 & & 7 & 5 & 9 & 0.270 & 6.79 & & 23 & 5 & 0 & 0 & 0 & 0 & $<0.01$ \\
\hline & & & & & 6 & 5.97 & & 26 & 9 & & 0 & 0 & 0 & .01 \\
\hline 5 & 24 & & 81 & -1 & 0.252 & 7.07 & +0.7 & 11 & 7 & 0 & 0 & 0 & 0 & $<0.01$ \\
\hline 7. & 1 & 7 & 5.18 & 8 & 0.311 & 6.02 & .7 & 9 & 21 & 0 & 0 & 0 & 0 & $<0.01$ \\
\hline 10 & & 6 & 15 & 13 & 0.347 & 9.54 & & 8 & 50 & 0 & 0 & 0 & 0 & $<0.01$ \\
\hline & . & 6. & 3.80 & 1 & 0.357 & 9.95 & & 3 & 88 & 0 & 0 & 0 & 0 & $<0.01$ \\
\hline & 7.7 & 6. & 3.40 & 14 & 0.338 & 10.09 & & 7 & 174 & 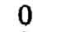 & 0 & 0 & 0 & 0.06 \\
\hline & 7.28 & 6 & 2.82 & 15.87 & 0.412 & 11.08 & & 26 & 210 & 0 & 0 & 0 & 0 & 0.16 \\
\hline & 6.60 & 6. & 1.37 & 1 & 0.345 & 11.90 & & 58 & 15 & 0 & 0 & 0 & 0 & 0.37 \\
\hline & - & & 0.6 & 30 & 0.3 & 4 & & 4 & 28 & 0 & 0 & 0 & 0 & 1.30 \\
\hline & 6.20 & 6 & 0 & 1 & 0.350 & 12.65 & & 5 & 265 & 1. & 7.2 & 0 & 0 & 0.47 \\
\hline & - & & & & & 12.65 & & 42 & 34 & 2. & - & & 0 & 1.16 \\
\hline & 6.10 & & & & & & & 222 & 12 & 2. & 10.1 & 0. & 0. & 1.30 \\
\hline & 6.01 & 6 & 0.0 & 15. & 0.371 & 17.60 & & 371 & 13 & 2.0 & - & 2.56 & 3. & 3.16 \\
\hline & - & & & & & & & 25 & 12 & 0 & 0 & & 4. & 3.90 \\
\hline & - & 6 & 0.0 & 14 & 0.3 & 18.72 & & 96 & 9 & 0 & 0 & & 5. & 9.50 \\
\hline & $\ldots$ & 6 & 0.00 & 14.90 & 0.344 & 18.72 & & 272 & 3 & 0 & 0 & 4.16 & 5.1 & 2.20 \\
\hline
\end{tabular}

Max, depth: $28.50 \mathrm{~m}$, 
of anoxic zone to a maximum of $343 \gamma / 1$ and then rapidly decreases downwards to be nearly absent. Nitrite and $\mathrm{NH}_{2} \mathrm{OH}$ appear first in the boundary layer at $22.5 \mathrm{~m}$ between oxic and anoxic zones, and increase downwards to a maximum at $25.0 \mathrm{~m}$ and then simultaneously decrease to be absent. Denitrified nitrogen is observed at almost all depths and its highest value of $1.9 \mathrm{ml} / 1$ is observed in a water layer at $21.5 \mathrm{~m}$, where $0.65 \mathrm{ml} / 1$ of dissolved oxygen is present. Methane begins to appear at $23.5 \mathrm{~m}$ and remarkably increases with depth.

These findings suggest that the chemical consequence of microbiological decomposition of inorganic and organic matter in Lake Kizaki-ko is similar to the following steps according to which the microbial reduction process takes place in waterlogged soils (Koyama, 1964). In the lake water, however, denitrification process takes place even in oxic zone.

(1) In the early stage of incubation of waterlogged soils, dissolved oxygen is first consumed and redoxpotential drops rapidly.

(2) $\mathrm{NO}_{3}^{-}$and $\mathrm{NO}_{2}^{-}$are reduced to $\mathrm{N}_{2}$.

(3) $\mathrm{Mn}^{4+}$ is reduced to $\mathrm{Mn}^{2+}$.

(4) $\mathrm{Fe}^{3+}$ is reduced to $\mathrm{Fe}^{2+}$.

(5) $\mathrm{SO}_{4}^{2-}$ is reduced to $\mathrm{S}^{2-}$.

(6) $\mathrm{H}_{2}$ and $\mathrm{CH}_{4}$ are formed.

Since the standard redoxpotentials of $\mathrm{Mn}^{4+} / \mathrm{Mn}^{2-}, \mathrm{Fe}^{3+} / \mathrm{Fe}^{2-}$ and $\mathrm{S} / \mathrm{S}^{2-}$ are +1.6 , +0.76 , and $-0.55 \mathrm{~V}$ respectively, the order of steps of the reduction process seems to be determined by each redoxpotential of these redox systems.

Fig. 12 shows a typical observation at the end of autumn stagnation period. This shows uniform distributions of water temperature, total $\mathrm{CO}_{2}, \mathrm{NO}_{3}^{-}-\mathrm{N}, \mathrm{NH}_{4}^{+}-\mathrm{N}$, and denitrified $\mathrm{N}_{2}$ in the water layers from surface to $15 \mathrm{~m}$ depth, with the exception of dissolved $\mathrm{O}_{2}$, which is easily consumed by reducing components migrating up from the bottom water. Such a uniform distribution of various components and such a small amount of denitrified $\mathrm{N}_{2}$ may be resulted by an active circulation of water in upper layers at the end of autumn stagnation period.

It is a noteworthy fact that in this period the amount of $\mathrm{NO}_{3}^{-}-\mathrm{N}$ is smaller than $10 \mathrm{r} / 1$ in all water layers even though it usually amounts to $200-300 \mathrm{r} / 1$ in the water layers between $12 \mathrm{~m}$ and $24 \mathrm{~m}$ depths in the period from the beginning of September through the beginning of November. This fact suggests that the greater part of nitrate is mixed with ammonium migrating up from the bottom water by the slow water circulation, and enzymatically reacts with ammonium to release nitrogen gas according to the following equation,

$$
5 \mathrm{NH}_{3}+3 \mathrm{HNO}_{3} \rightarrow 4 \mathrm{~N}_{2}+9 \mathrm{H}_{2} \mathrm{O},
$$

and the denitrified $\mathrm{N}_{2}$ is released from the water into the atmosphere. The enzymatic reaction is not yet confirmed microbiologically. This process, however, should be made clear in the near future. 


\section{Role of denitrification in nitrogen metabolism}

A glance at the figures of seasonal observations shows that during the early stage of a stagnation period, nitrogen fixation is generally more active than denitrification, on the contrary, during a stagnation period, denitrification gradually exceeds nitrogen fixation with the progress of stagnation. At the end of the stagnation period, the amount of denitrified $\mathrm{N}_{2}$ is considerably large as compared with those of the other mineralized nitrogenous compounds such as $\mathrm{NH}_{4}^{+}, \mathrm{NH}_{2} \mathrm{OH}, \mathrm{NO}_{2}^{-}$, and $\mathrm{NO}_{3}^{-}$. Thus the denitrification constitutes the dominant process determining the nitrogen metabolism in the lake water.

\section{Ratio of mineralized carbon to mineralized nitrogen}

From the result in Table 2, the mineralized carbon (miner. $\mathrm{C}$ ) and mineralized nitrogen (miner. $\mathrm{N}$ ) at various depths were calculated according to the following equations:

$$
\begin{aligned}
\text { Miner. } \mathrm{C}(\mathrm{mg} / \mathrm{l}) & =\left[\left(\text { total } \mathrm{CO}_{2}-\text { orig. } \mathrm{CO}_{2}^{*}\right)+\mathrm{CH}_{4}\right](\mathrm{ml} / 1) \times 0.536, \\
& =\left[\left(\text { total } \mathrm{CO}_{2}-6.45\right)+\mathrm{CH}_{4}\right](\mathrm{ml} / 1) \times 0.536 . \\
\text { Miner. } \mathrm{N}(\mathrm{mg} / \mathrm{l}) & =\text { Denitrified } \mathrm{N}_{2}(\mathrm{ml} / 1) \times 1.25+\left(\mathrm{NH}_{4}^{+}-\mathrm{N}+\mathrm{NH}_{2} \mathrm{OH} \cdot \mathrm{N}\right. \\
& \left.+\mathrm{NO}_{2}^{-}-\mathrm{N}+\mathrm{NO}_{3}^{-}-\mathrm{N}\right)(r / 1) \times 10^{-3} .
\end{aligned}
$$

* Orig. $\mathrm{CO}_{2}$ : Amount of total carbon dioxide which was not affected by the activity of organisms after a thermal stratification had been established and thus existed originally. In this paper, this amount was assumed to be the average value of the total carbon dioxide in surface and subsurface water layers which are almost saturated with air and calculated as $6.45 \mathrm{ml} / 1$ in September and October, 1963; 6.98 $\mathrm{ml} / 1$ in November, 1965; and $7.86 \mathrm{ml} / 1$ in October, 1966.

The amounts of total mineralized carbon and nitrogen in a vertical water column of Lake Kizaki-ko, with a sectional area of $100 \mathrm{~cm}^{2}$ and as deep as the lake, are calculated as $746 \mathrm{mg}$ and $258 \mathrm{mg}$ respectively on 7-8 September, 1963. Other calculated values for all of the seasonal observations are summarized in Table 3 , in which negative values may indicate assimilated nitrogen. This table shows that after a thermal stagnation has been established, the amounts of mineralized carbon and nitrogen gradually increase towards the end of the stagnation period as a result of their accumulation in the lake water. It may be significant that the absolute value of the negative amount $(-212 \mathrm{mg})$ of total mineralized nitrogen in April, 1964 is comparable with that of the average amount $(230 \mathrm{mg})$ at the end of the stagnation period.

From the observed data in September and October 1963, November 1964, November 1965, and October 1966, the average ratio of total mineralized carbon to total mineralized nitrogen, $(807 \mathrm{mg} / 230 \mathrm{mg})$, at the end of the stagnation period was calculated as 3.5 , a value considerably smaller than the $\mathrm{C} / \mathrm{N}$ ratio for plankton, 5.7. This fact supports the view that the greater ease of the mineralization of nitrogenous fraction of dead planktonic material as compared with that of car- 
Table 3. Seasonal variation of various mineralized $\mathrm{C}$ and $\mathrm{N}$ in a vertical water column in Lake Kizaki-ko, with a sectional area of $100 \mathrm{~cm}^{2}$ and as deep as the lake

\begin{tabular}{|c|c|c|c|c|c|c|c|c|c|c|c|c|}
\hline & $\begin{array}{l}1965 \\
\text { Mar. }\end{array}$ & $\begin{array}{l}1966 \\
\text { Mar. }\end{array}$ & $\begin{array}{l}1964 \\
\text { Apr. }\end{array}$ & $\begin{array}{l}1963 \\
\text { May }\end{array}$ & $\begin{array}{l}1965 \\
\text { July }\end{array}$ & $\begin{array}{l}1964 \\
\text { July }\end{array}$ & $\begin{array}{l}1963 \\
\text { Sept. }\end{array}$ & $\begin{array}{l}1966 \\
\text { Oct. }\end{array}$ & $\begin{array}{l}1963 \\
\text { Oct. }\end{array}$ & $\begin{array}{l}1965 \\
\text { Nov. }\end{array}$ & $\begin{array}{l}1964 \\
\text { Nov. }\end{array}$ \\
\hline \multicolumn{2}{|c|}{$\begin{array}{c}\text { Surface Water Temp. } \\
\left({ }^{\circ} \mathrm{C}\right)\end{array}$} & 3.18 & 5.35 & 13.70 & 19.00 & 20.00 & 25.50 & 21.80 & 14.71 & 13.50 & 13.00 & 9.40 \\
\hline \multirow{2}{*}{$\begin{array}{c}\text { Total } \\
\text { miner. } \\
\text { C (mg) }\end{array}$} & $\begin{array}{l}\text { Total } \mathrm{CO}_{2} \cdot \mathrm{C} \\
\mathrm{CH}_{4}-\mathrm{C}\end{array}$ & 165 & -8.5 & 113 & 263 & 496 & $\begin{array}{r}442 \\
30\end{array}$ & $\begin{array}{r}706 \\
40\end{array}$ & $\begin{array}{r}653 \\
71\end{array}$ & $\begin{array}{l}718 \\
130\end{array}$ & $\begin{array}{r}813 \\
55\end{array}$ & $\begin{array}{r}805 \\
47\end{array}$ \\
\hline & Tot & 165 & 8.5 & 113 & 263 & 496 & 472 & 746 & 724 & 848 & 868 & 852 \\
\hline \multirow{5}{*}{$\begin{array}{c}\text { Total } \\
\text { miner. } \\
N(\mathbf{m g})\end{array}$} & $\mathrm{NO}_{3}^{-}-\mathrm{N}$ & 13.2 & 29.6 & 28.8 & 23.1 & 34.9 & 38.7 & 28.9 & 28.9 & 32.5 & 40.1 & 2.2 \\
\hline & $\mathrm{NH}_{4}^{+}-\mathrm{N}$ & 8.2 & 11.9 & 18.7 & 23.2 & 19.8 & 23.4 & 18.8 & 39.6 & 28.6 & 32.2 & 30.3 \\
\hline & $\mathrm{NO}_{2}^{-}, \mathrm{NH}_{2} \mathrm{OH}-\mathrm{N}$ & - & - & - & - & - & - & - & 2.3 & 5.4 & 2.6 & - \\
\hline & Denitrified $\mathrm{N}_{2}$ & +49 & -44 & $|-260|$ & -38 & $-100 \mid$ & +130 & +210 & +160 & +130 & +230 & +120 \\
\hline & Total $\mathrm{N}$ & 67 & -2 & $|-212|$ & 8 & -45 & 192 & 258 & 231 & 197 & 305 & 152 \\
\hline
\end{tabular}

bonaceous fraction causes the increase in the ratio of org. $\mathrm{C} / \mathrm{org} . \mathrm{N}$ of organic detritus from upper water layers towards the bottom.

The decomposition rates of organic $\mathrm{C}$ and $\mathrm{N}$ in detritus into soluble organic $\mathrm{C}$ and $\mathrm{N}$ may also vary the $\mathrm{C} / \mathrm{N}$ ratio of organic detritus. Therefore, seasonal observations are now being continued in Lake Kizaki-ko in order to make clear this problem.

\section{Relationship between mineralization and sedimentation rates of organic matter}

On the assumption that the mineralization rates of organic carbon and nitrogen in the winter circulation period are considerably small as compared with those in the summer stagnation period, the mineralization rates of organic carbon and nitrogen were assumed to be close to $807 \mathrm{mg} / \mathrm{y}$ and $230 \mathrm{mg} / \mathrm{y}$ respectively in the water column as mentioned above.

The sedimentation rates of organic carbon and nitrogen were estimated from the results shown in Table 4 as $780 \mathrm{mg} / 100 \mathrm{~cm}^{2} \cdot \mathrm{y}$ and $74 \mathrm{mg} / 100 \mathrm{~cm}^{2} \cdot \mathrm{y}$ respectively. If the organic matter in the lake water had not been subjected to microbiological

Table 4. Sedimentation rates of detritus at various depths in Lake Kizaki-ko and the ratio of organic $\mathrm{C}$ to $\mathrm{N}$

\begin{tabular}{c|c|c|c|c}
\hline $\begin{array}{c}\text { Depth } \\
(\mathrm{m})\end{array}$ & $\begin{array}{c}\text { Dried matter } \\
\text { at } 110^{\circ} \mathrm{C} \\
\left(\mathrm{g} / 100 \mathrm{~cm}^{2} / \mathrm{y}\right)\end{array}$ & $\begin{array}{c}\text { Org. C } \\
\left(\mathrm{mg} / 100 \mathrm{~cm}^{2} \cdot \mathrm{y}\right)\end{array}$ & $\begin{array}{c}\text { Org. N } \\
\left(\mathrm{mg} / 100 \mathrm{~cm}^{2} \cdot \mathrm{y}\right)\end{array}$ & $\begin{array}{c}\text { Org. C } \\
\text { Org. N }\end{array}$ \\
\hline 25.5 & 13.3 & 740 & 65 & 11.4 \\
27.0 & 14.2 & 710 & 74 & 9.6 \\
27.5 & 15.3 & 780 & 75 & 10.4 \\
28.5 & 15.3 & 900 & 80 & 11.3 \\
\hline Average & 14.5 & 780 & 74 & 10.7 \\
\hline
\end{tabular}

The sedimentation rates were calculated on the basis of amounts of detritus settled at various depths from July 13, 1965 through October $31,1966$. 
decomposition, the sedimentation rates of organic carbon and nitrogen would be $1,587,(780+807), \mathrm{mg} / 100 \mathrm{~cm}^{2} \cdot \mathrm{y}$ and $304,(74+230), \mathrm{mg} / 100 \mathrm{~cm}^{2} \cdot \mathrm{y}$ respectively. The mineralization rates of carbon and nitrogen in the organic detritus, therefore, are estimated as $51 \% / \mathrm{y},(807 / 1587) \times 100$, and $76 \% / \mathrm{y},(230 / 304) \times 100$, respectively.

\section{Denitrification process in oxic zone}

As is generally known, denitrified $\mathrm{N}_{2}$ is produced as one of the final products in the microbiological reduction process of $\mathrm{NO}_{3}^{-}$or $\mathrm{NO}_{2}^{-}$in anoxic zone. In natural water, the reduction may take place in anoxic zone according to a process similar to the following equation proposed by RICHARDS (1964):

$$
\left(\mathrm{CH}_{2} \mathrm{O}\right)_{106}\left(\mathrm{NH}_{3}\right)_{16} \cdot \mathrm{H}_{3} \mathrm{PO}_{4}+94.4 \mathrm{HNO}_{3} \rightarrow 106 \mathrm{CO}_{2}+55.2 \mathrm{~N}_{2}+177.2 \mathrm{H}_{2} \mathrm{O}+\mathrm{H}_{3} \mathrm{PO}_{4},
$$

where $\left(\mathrm{CH}_{2} \mathrm{O}\right)_{106}\left(\mathrm{NH}_{3}\right)_{16} \cdot \mathrm{H}_{3} \mathrm{PO}_{4}$ is the hypothetical composition of organic matter of planktonic origin. In our case, however, the denitrification actively takes place rather in the oxic zone of the lake.

Table 5 shows the relationship of the observed total $\mathrm{CO}_{2}$ to the theoretical total $\mathrm{CO}_{2}$ and the denitrified $\mathrm{N}_{2}$. The theoretical total $\mathrm{CO}_{2}(\mathrm{~A})$ and (B) were calculated based on original $\mathrm{CO}_{2}$, consumed $\mathrm{O}_{2}$ and two kinds of respiration quotients, 0.85 recommended by OHLE, for (A) and 0.89 calculated from the overall reaction (1),

Table 5. Relationship between total $\mathrm{CO}_{2}$ and denitrified $\mathrm{N}_{2}$ in Lake Kizaki-ko

\begin{tabular}{|c|c|c|c|c|c|c|c|c|}
\hline \multirow{2}{*}{ Date } & \multirow{2}{*}{$\begin{array}{l}\text { Depth } \\
(\mathrm{m})\end{array}$} & \multirow{2}{*}{$\begin{array}{c}\text { Ar } \\
(\mathrm{ml} / 1)\end{array}$} & \multirow{2}{*}{$\begin{array}{c}\text { Observ. } \\
\mathrm{O}_{2} \\
(\mathrm{ml} / 1)\end{array}$} & \multirow{2}{*}{$\begin{array}{c}\text { Theor. } \\
\mathrm{O}_{2} \\
(\mathrm{ml} / \mathrm{l})\end{array}$} & \multirow{2}{*}{$\begin{array}{c}\text { Observ. } \\
\text { total } \\
\mathrm{CO}_{2} \\
(\mathrm{ml} / 1)\end{array}$} & \multicolumn{2}{|c|}{$\begin{array}{c}\text { Theor. total } \\
\mathrm{CO}_{2}\end{array}$} & \multirow{2}{*}{$\begin{array}{c}\text { Denitrified } \\
\mathrm{N}_{2} \\
(\mathrm{ml} / 1)\end{array}$} \\
\hline & & & & & & $\begin{array}{c}\text { (A) } \\
(\mathrm{ml} / 1)\end{array}$ & $\begin{array}{c}\text { (B) } \\
(\mathrm{ml} / \mathrm{l})\end{array}$ & \\
\hline Sept. 7-8, 1963 & $\begin{array}{l}20.0 \\
21.5 \\
22.5\end{array}$ & $\begin{array}{l}0.345 \\
0.341 \\
0.350\end{array}$ & $\begin{array}{l}1.37 \\
0.65 \\
0.83\end{array}$ & $\begin{array}{l}7.28 \\
7.19 \\
7.39\end{array}$ & $\begin{array}{l}11.90 \\
13.14 \\
12.65\end{array}$ & $\begin{array}{l}11.47 \\
12.00 \\
12.02\end{array}$ & $\begin{array}{l}12.00 \\
12.56 \\
12.60\end{array}$ & $\begin{array}{l}1.1 \\
1.9 \\
1.1\end{array}$ \\
\hline Oct. $28-29,1963$ & $\begin{array}{l}10.0 \\
12.5 \\
15.0\end{array}$ & $\begin{array}{l}0.330 \\
0.338 \\
0.340\end{array}$ & $\begin{array}{l}6.23 \\
2.38 \\
2.21\end{array}$ & $\begin{array}{l}6.97 \\
7.13 \\
7.19\end{array}$ & $\begin{array}{r}7.78 \\
10.85 \\
11.30\end{array}$ & $\begin{array}{r}7.08 \\
10.50 \\
10.68\end{array}$ & $\begin{array}{r}7.40 \\
11.00 \\
11.18\end{array}$ & $\begin{array}{l}1.7 \\
1.6 \\
1.5\end{array}$ \\
\hline Nov. 1-2, 1965 & $\begin{array}{r}7.5 \\
10.0 \\
12.5\end{array}$ & $\begin{array}{l}0.275 \\
0.333 \\
0.356\end{array}$ & $\begin{array}{l}5.22 \\
2.59 \\
2.41\end{array}$ & $\begin{array}{l}5.82 \\
7.04 \\
7.52\end{array}$ & $\begin{array}{r}8.47 \\
11.87 \\
11.90\end{array}$ & $\begin{array}{r}7.49 \\
10.76 \\
11.33\end{array}$ & $\begin{array}{r}7.83 \\
11.26 \\
11.86\end{array}$ & $\begin{array}{l}1.2 \\
1.3 \\
0.5\end{array}$ \\
\hline
\end{tabular}

Theor. total $\mathrm{CO}_{2}(\mathrm{~A})=$ Original total $\mathrm{CO}_{2}+\Delta \mathrm{O}_{2} \times 0.85^{*}$.

Theor. total $\mathrm{CO}_{2}(\mathrm{~B})=$ Original total $\mathrm{CO}_{2}+\Delta \mathrm{O}_{2} \times 0.89 * *$.

Original total $\mathrm{CO}_{2}$ : The amount of total $\mathrm{CO}_{2}$ which was not affected by the activity of organisms after the thermal stratification had been established and thus existed originally. This is assumed in this paper to be the average amount of total $\mathrm{CO}_{2}$ in the upper water layers which are almost saturated with air and calculated to be $6.45 \mathrm{ml} / \mathrm{l}$ in September and October 1963 and $6.98 \mathrm{ml} / 1$ in November 1965.

$\mathrm{SO}_{2}=$ Theor, $\mathrm{O}_{2}$ - Observ. $\mathrm{O}_{2}$.

Theor. $\mathrm{O}_{2}$ : The amount of the dissolved oxygen calculated on the basis of the argon content.

* 0.85: Respiratory quotient recommended by OHLE.

** 0.86: Respiratory quotient calculated on the basis of the following equation: $4 \mathrm{CH}_{2} \mathrm{NH}_{2} \cdot \mathrm{COOH}+9 \mathrm{O}_{2} \rightarrow 8 \mathrm{CO}_{2}+2 \mathrm{~N}_{2}+10 \mathrm{H}_{2} \mathrm{O}$. 
for (B) as shown in the table. The table indicates that the amounts of the observed total $\mathrm{CO}_{2}$ are closer to the values of the theoretical total $\mathrm{CO}_{2}$ (B) than to those of (A) and that with a few exceptions the amounts of denitrified $\mathrm{N}_{2}$ correspond to about one-fourth of the amounts of consumed $\mathrm{O}_{2}$. In consideration of the relationship in Table 5 , the denitrification which would take place in the oxic zone may be stoichiometrically similar to the following overall reaction for the enzymatic oxidation of glycine with dissolved oxygen:

(1) $4 \mathrm{CH}_{2} \mathrm{NH}_{2} \cdot \mathrm{COOH}+9 \mathrm{O}_{2} \rightarrow 8 \mathrm{CO}_{2}+2 \mathrm{~N}_{2}+10 \mathrm{H}_{2} \mathrm{O}$,

which is a combination of the following three enzymatic reactions, though the final reaction is not yet confirmed microbiologically:

(2) $2 \mathrm{CH}_{2} \mathrm{NH}_{2} \cdot \mathrm{COOH}+3 \mathrm{O}_{2} \rightarrow 4 \mathrm{CO}_{2}+2 \mathrm{NH}_{3}+2 \mathrm{H}_{2} \mathrm{O}$,

(3) $\mathrm{NH}_{3}+2 \mathrm{O}_{2} \rightarrow \mathrm{HNO}_{3}+\mathrm{H}_{2} \mathrm{O}$, and

(4) $5 \mathrm{NH}_{3}+3 \mathrm{HNO}_{3} \rightarrow 4 \mathrm{~N}_{2}+9 \mathrm{H}_{2} \mathrm{O}$.

These reactions could form conjectures upon denitrification in oxic zone. Some model experiments would conclude in the near future whether the reactions do or do not take place in lake water.

\section{ACKNowledgemENTS}

This research was supported in part by the Scientific Research grant-in-aid of the Ministry of Education and in part by the National Sectional Committees for PF, PM and PP in the International Biological Programme in Japan (JIBP).

We wish to express our thanks to Professor T. Mori and Dr. H. Iwasaki, Department of Biology, Faculty of Science, Nagoya University, for their helpful suggestions and discussions, and also to Professor S. OANA, Department of Earth Sciences in the same faculty, for his critical reading the manuscript.

\section{References}

Botan, E. A., Miller, J. J. and KleERekoper, H. (1960) A study of the microbiological decomposition of nitrogenous matter in fresh water. Arch. f. Hydrobiol. 56, 334-353.

BRAND, VON and RAKESTRAW, N. W. (1937) Decomposition and regeneration of nitrogenous organic matter in sea water. Biol. Bull. Woods Hole. 72, 165-175.

BRAND, VON and RAKESTRAW, N. W. (1939) Further experiments on the decomposition and regeneration of nitrogenous organic matter in sea water. ibid. 77, 285-296.

BRAND, VON and RAKESTRAW, N. W. (1940) Decomposition and regeneration of nitrogenous organic matter in sea water (III). Influence of temperature and source and condition of water. ibid. 79, 22-36.

BRAND, VON and RAKESTRAw, N. W. (1941) Decomposition and regeneration of nitrogenous organic matter in sea water (IV). Interrelationship of various stages; influence of concentration and nature of particulate matter. ibid. 81, 63-69.

BRAND, VON, RAKESTRAW, N. W. and ZOBOR, J. W. (1942) Decomposition and regeneration of nitrogenous organic matter in sea water (V). Factors influencing the length of the cycle; observations upon the gaseous and dissolved organic nitrogen. ibid. 83, 273-282.

DUURSMA, E. K. (1961) Dissolved organic carbon, nitrogen and phosphorus in the sea. Netherlands J. Sea Res. 1, 1-148. 
ENDRES, G, and KAUfman, L. (1937) Die Bestimmung kleinster Mengen von Hydroxylamin, Nitrit und Nitrat. Ann. Chem. 530, 184-194.

FRAGA, F. (1966) Distribution of particulate and dissolved nitrogen in the western Indian Ocean. Deep-Sea Res. 13, 413-425.

KLEEREKOPER, H. (1953) The mineralization of plankton. J. Fish. Res. Bd. Can. 10, 283-291.

Koy AMA, T. (1953) Measurement and analysis of gases in sediments. J. Earth Sci. Nagoya Univ. 1, 107-118.

KOYAMA, T. (1954) Distribution of carbon and nitrogen in lake muds. ibid. 2, 5-14.

KOYAMA, T. (1964) Biogeochemical studies on lake sediments and paddy soils and the production of atmospheric methane and hydrogen. Recent researches in the fields of hydrosphere, atmosphere and nuclear geochemistry. SUGAWARA Festival Volume. Maruzen Co. Ltd., Tokyo, Japan.

KOYAMA, T. and Tomino, T. (1967) Mineralization process of organic matter in lake water. Bull. Misaki Mar. Biol. Inst. Tokyo Univ. Special No. (in press).

MulliN, J. B. and RILEY, J. P. (1955) The spectrophotometric determination of nitrate in natural waters, with particular reference to sea-water. Anal. Chem. Acta 12, 464-480.

OANA, S. (1957) Bestimmung des Argon im besonderen Hinblick auf gelöste Gase in natürlichen Wässern. J. Earth Sci. Nagoya Univ. 5, 103-124.

RICHARDS, F. A. (1964) Chemical observations in some anoxic, sulfide bearing basins and fjords. Second International Conference on Water Pollution, Tokyo.

SAIJO, Y. (1956) Chemical studies in lake metabolism, (1). J. Chem. Soc. Japan. 77, 917-923; (2). ibid. 77, 923-926; (3). ibid. 77, 926-930; (4). ibid. 77, 930-936; (5). ibid. 77, 1184-1187; (6). ibid. 77, 1187-1190; (7). ibid. 77, 1190-1192; (8). ibid. 77, 1192-1196.

SugawARA, K. (1939) Chemical studies in lake metabolism. Bull. Chem. Soc. Japan. 14, 375451.

TANAKA, M. (1951 a) Colorimetric microdetermination of manganese in the field (in Japanese). J. Chem. Soc. Japan, Pure Chem. Sect. 22, 29-34.

TANAKA, M. (1951 b) Application of mercuric salt to the colorimetric determination of manganese (in Japanese). ibid. 72, 136-138.

TANAKA, M. (1954) Hydroxylamine dans les eaux lacustres. Variation saisonnière et importance biogéochimique. Bull. Chem. Soc. Japan. 27, 200-203.

WAKsman, S. A., CARey. C. L. and Reuszer, H. R. (1933) Marine bacteria and their role in the cycle of life in the sea. Biol. Bull. 65, 57-79. 